\title{
Response of Irish Creamery Milk Supply to Price Changes
}

\author{
MICHAEL P. CUDDY* \\ University College, Galway
}

Précis: This article investigates the responsiveness of creamery milk supply to changes in the price of milk relative to agricultural materials. A basic model, which includes milk and livestock price variables and a Gini coefficient of cow concentration (a proxy for technological change) is modified to test pre- and post-EEC response differences. The effects of the milk price variables are isolated using the method of principal components. Price responsiveness was higher in the post- than pre-EEC period with largest responses shown after a two to three year lag. The technology effect although positive was not significant.

\section{INTRODUCTION}

7 he purpose of this study is to examine the effect of price change on creamery milk supply in Ireland. This is of particular interest in the light of what happened to prices before entry and after entry into the EEC, and what is likely to happen as a result of the current surplus milk production.

Previous studies on Irish milk production have concentrated on explaining supply and its structure through explaining dairy cow numbers (Buttimer (1972), O'Connor (1972), Keane (1977), O'Neill and Herlihy (1977)). In the present study, a reduced form milk supply function which includes milk price variables is developed, and the parameters are estimated. An inter-

*The author wishes to thank G. Boyle of the Central Bank, J. Higgins of An Foras Talúntais and an anonymous referee for their helpful comments on previous drafts of this paper. He also wishes to thank G. Kelly and M. O'Reilly for their help in processing the data. The author alone is responsible for any errors. 
action term is then introduced to test for response differences in the pre-EEC period (Period I) and post-EEC period (Period II). The milk price variables are the focus of attention. Therefore, using the same basic model, a stepwise procedure is adopted in estimating the parameters of the milk price variables, using principal components to collapse all but one of the other explanatory price variables.

The model and data are presented in Section II. The results are presented in Section III and the summary and conclusions in Section IV.

\section{MODEL AND DATA}

The price of milk has been exogenously determined over the period covered, first, by Irish Government intervention in the pre-EEC period, and secondly, by the EEC's Common Agricultural Policy in the post-EEC period. Consequently, a demand equation has no role to play in the model. Thus we concentrate on the supply side alone.

The supply of milk is a function of cow numbers and level of yield:

$$
\begin{aligned}
& \mathrm{M}=\mathrm{f}_{1}(\mathrm{Y}, \mathrm{C}) \\
& \text { where } \mathbf{M}=\text { milk supply } \\
& \mathrm{Y}=\text { yield } \\
& \mathrm{C}=\text { cow numbers }
\end{aligned}
$$

Yield depends on the level of technology, and the level of inputs used. The latter in turn depends on the milk/inputs price ratio:

$$
\begin{aligned}
\mathrm{Y} & =\mathrm{f}_{2}\left(\mathrm{~T}, \mathrm{P}_{\mathrm{m}} / \mathrm{P}_{\mathrm{I}}\right) \\
\text { where } \mathrm{T} & =\text { level of technology } \\
\mathrm{P}_{\mathrm{m}} & =\text { price of milk } \\
\mathrm{P}_{\mathrm{I}} & =\text { price of inputs }
\end{aligned}
$$

Cow numbers depend on the milk/inputs price ratio and the ratio of the price of alternative agricultural output to the price of inputs:

$$
\mathrm{C}=\mathrm{f}_{3}\left(\mathrm{P}_{\mathrm{m}} / \mathrm{P}_{\mathrm{I}}, \mathrm{P}_{\mathrm{A}} / \mathrm{P}_{\mathrm{I}}\right)
$$

where $\mathrm{P}_{\mathrm{A}}=$ price of alternative product, while the other variables are as already defined.

Equations (1), (2) and (3) can be combined to give a single equation model of milk supply:

$$
M=f_{4}\left(T, P_{m} / P_{I}, P_{A} / P_{I}\right)
$$

The first question which arises is that of the appropriate substitutes for milk and thus the appropriate alternative price variable to include. Halvorson (1958) using a milk supply equation similar to (4) above found that from 
among various alternatives, only beef prices had a significant effect. Prato (1973) assumes beef is the only important substitute for dairy cows, although O'Connor (1972) did find cereal prices to be significant in explaining dairy cow numbers, in two out of three equations. Buttimer (1972) found neither the grain price nor the price of crops, when used in separate equations, to significantly affect cow numbers. Indeed in the Irish context given that tillage is a marginal agricultural activity relative to dairying and the tendency for tillage to be more and more concentrated with increases in technology, it is unlikely that the switching from tillage to milk resulting from relative price change would be significant. This would seem to be the opinion of O'Neill and Herlihy (1977) where the only alternate product considered in their equation for dairy cows is beef. Beef is thus the only alternative product considered in this study. However, the price of cereals, to the extent that they are included in the price of inputs, is also included in the model.

A second question concerns the length of lag to be used, since milk supply in any year is to some extent the result of decisions taken in previous years. The yield can change quite quickly with increased feedstuff usage, but the change in cow numbers requires time. The change in cow numbers can come from both existing milk producers and new producers. One can argue that for existing producers, allowing a lag in decision-making, the increased cow responses and the corresponding milk increase will have taken place within a two to three year period after the initial price change. This time period should also be sufficient to allow new producers to switch from alternative activities, especially beef.

A third question concerns the inclusion of an appropriate variable to take account of technological change. Time, which is usually included for this purpose, is not very appropriate since, for example, in a linear model it assumes that technological change takes place in a perfectly linear fashion, which may not necessarily be the case. If, however, one assumes that increased specialisation in milk production is accompanied by improved technology, then a Gini co-efficient measuring the degree of dairy cow concentration, and thus specialisation, is an appropriate proxy for the level of technology. It must be recognised that this variable will also pick up the effect of economies of scale which is in fact closely related to the level of technology. This is not, however, considered a problem here since the primary interest is in the milk price variables.

It is reasonable to expect that the EEC would have some impact on milk supply response. Irish agriculture was already reacting to anticipated entry some years prior to actual entry. At government level various policies were implemented to encourage agricultural output in order to take advantage of the special concessions to agriculture, when the negotiations were finally concluded. As will be seen later, cow concentration increased rapidly between 
1965 and 1970 and remained static thereafter in dicating that by 1970 certain adjustments had already taken place. The study period was thus broken into Period I which extended from 1952 to 1968, and Period II which extended from 1969 to 1978. Period II commenced in 1969 since it coincided with the introduction of the Beef Incentive Scheme which was continued as a new scheme after entry into the EEC. A dummy variable was used to distinguish Period I from Period II.

Finally, a Calved Heifer Grant Scheme which encouraged cow numbers was in operation from 1964 to 1967 and a dummy variable was also used for the years in which the scheme operated.

The basic model constructed is thus:

$$
\begin{aligned}
& M_{t}=\beta_{o}+\sum_{i=1}^{2} \beta_{i} D_{i}+\sum_{j=0}^{3} \beta_{j} P_{m t-j}+\sum_{k=0}^{3} \beta_{k} p_{\ell t-k}+\beta_{11} G_{t}+\epsilon_{t} \\
& \text { where } \mathrm{M}_{\mathrm{t}} \quad=\text { creamery milk supply in year } \mathrm{t}(, 000 \text { gals. }) \\
& \mathrm{D}_{1} \quad=1 \text {, when the Calved Heifer Grant Scheme was in opera- } \\
& \text { tion } \\
& =0 \text {, otherwise } \\
& \mathrm{D}_{2} \quad=1, \text { in Period II (1969-1978) } \\
& =0 \text {, in Period I (1952-1968) } \\
& P_{m t-j}=\text { Ratio of the price of creamery milk to the price of } \\
& \text { agricultural materials in year } t-j \\
& \mathrm{P}_{\mathrm{mt}-\mathrm{k}}=\text { Ratio of the Price of Livestock to price of agricultural } \\
& \text { materials in year } \mathrm{t}-\mathrm{k} \\
& \mathrm{G}_{\mathrm{t}}=\text { Gini co-efficient for cow concentration in year } \mathrm{t} \\
& \epsilon_{\mathrm{t}} \quad=\text { Error term, which is assumed to be normally distri- }
\end{aligned}
$$

The basic model was adjusted in two ways. First, an interaction term between $\mathrm{D}_{2}$ and $\mathrm{P}_{\mathrm{mt}}$ was introduced to see if there was a different price effect response over the period of EEC influence and the pre-EEC period. Second, the basic model, both with and without an interaction term, was adjusted by a stepwise procedure attempting to isolate the price of milk effect for the current period and each of the lagged periods. Since at each step only a particular milk price effect was of interest, the other milk price variables and the livestock price variables were collapsed into their principal components. This procedure, allowing some extra degrees of freedom, adds to the precision of the parameter estimates and in addition reduces the multicollinearity problem associated with the high correlation between the milk price variables. When account is taken of the various adjustments there are in all 10 model variants. 
Annual data are used for the period 1952 to 1978. Milk deliveries to creameries, the Agricultural Materials Price Index, the Livestock Price Index and the data for deriving the Gini co-efficient were taken from the Irish Statistical Bulletin (various issues). All indices were set to a base of 1953=100. The price of milk series was provided by the Department of Agriculture. The Gini co-efficient measuring cow concentration was derived from the relationship between the cumulative percentage of cows and the cumulative percentage of holdings, where the latter proceeds from the smallest to the largest herds. Since the necessary data for estimating the Gini co-efficient are only available at five year intervals the values for the intervening years were derived by linear extrapolation. Although this can induce autocorrelation, in the event, it did not become a problem. It may be noted that the Gini co-efficient increased steadily from 0.28 in 1950 to 0.47 in 1965 , increased rapidly to 0.64 in 1970 and remained constant between 1970 and 1975. Although certain changes in the cow distribution by herd size did take place in this latter period, the Gini co-efficient was not, however, sensitive to these changes. The dummy variable for the Calved Heifer Grant Scheme is 1 for years 1964 to 1967 , and 0 for all other years. The dummy variable which takes account of the Beef Incentive Scheme and the EEC influence is 1 for 1969 to 1978 and 0 for all other years.

Model variant $I$ is the basic model while model variant II includes interaction terms between $D_{2}$ and $P_{m}$. In model variants III to $X$ the milk and livestock price variables other than the particular milk price variable under investigation, are collapsed into their principal components. In each model variant three principal components are used, $\mathrm{PC}_{1}, \mathrm{PC}_{2}, \mathrm{PC}_{3}$. These account in each case for over 92 per cent of the variation in the milk and livestock price variables, other than the particular one under investigation.

\section{REGRESSION RESULTS FOR MODEL VARIANTS I TO X}

The focus of this paper is the impact of milk price change on creamery milk supply. All model variants perform fairly well in terms of $R^{2}$, although some explanatory power is lost in the model variants where principal components are used (Table 1). This latter result is explained by the fact that only 92 per cent of the variation in the collapsed price variables is picked up by the resulting principal components. Consequently, the milk supply response to the explicit milk price variables in model variants III to $\mathrm{X}$ is possibly exaggerated. Since the Durbin-Watson statistic lies in the indeterminate zone for all model variants we can in no case accept a null hypothesis of either positive or negative autocorrelation.

A one tailed t-test shows the parameter estimates of $\mathrm{P}_{\mathrm{mt}}, \mathrm{P}_{\mathrm{mt}-1}$ and $\mathrm{P}_{\mathrm{mt}-3}$ in model variant $I$ to be significant at the 5 per cent level. However, 
Table 1: Parameter estimates for the variables, $t$ and Durbin.Watson (DW) statistics and $\bar{R}^{2}$ for ten model variants of creamery milk supply

\begin{tabular}{|c|c|c|c|c|c|c|c|c|c|c|c|c|c|c|c|c|c|c|c|c|c|}
\hline & Constant & $P_{m t}$ & $P_{m t-1}$ & $P_{m t-2}$ & $P_{m t-3}$ & $D_{2}^{P} P_{t}$ & $D_{2} P_{m t-1}$ & $D_{2}^{P}{ }_{m t-2}$ & ${ }_{2} D_{2}{ }_{m t-3}$ & $P_{\ell_{t}}$ & $P_{l_{t-1}}$ & $P_{Q t-2}^{\prime}$ & $P_{l t-3}$ & $P C_{1}$ & $P C_{2}$ & $P C_{3}$ & $D_{1}$ & $D_{2}$ & $G_{t}$ & $D W$ & $\vec{R}^{2}$ \\
\hline I & -167 & $\begin{array}{l}3,425 \\
(2.38)\end{array}$ & $\begin{array}{l}5,388 \\
(9.16)\end{array}$ & $\begin{array}{l}1,415 \\
(0.60)\end{array}$ & $\begin{array}{l}\mathbf{3}, 581 \\
(1.81)\end{array}$ & & & & & $\begin{array}{c}-145 \\
(-1.04)\end{array}$ & $\begin{array}{c}-254 \\
(-1.85)\end{array}$ & $\begin{array}{l}-217 \\
(-2.30)\end{array}$ & $\begin{array}{c}-241 \\
(-2.59)\end{array}$ & & & & $\begin{array}{r}-41.8 \\
(-0.91)\end{array}$ & $\begin{array}{r}81.8 \\
(1.12)\end{array}$ & $\begin{array}{c}467 \\
(1.55)\end{array}$ & 1.87 & 0.96 \\
\hline II & 110 & $\begin{array}{r}249 \\
(0.81)\end{array}$ & $\begin{array}{l}4,225 \\
(0.89)\end{array}$ & $\begin{array}{l}-1,927 \\
(-0.41)\end{array}$ & $\begin{array}{l}2,816 \\
(0.80)\end{array}$ & $\begin{array}{l}3,904 \\
(0.94)\end{array}$ & $\begin{array}{r}183 \\
(0.33)\end{array}$ & $\begin{array}{l}3,245 \\
(0.77)\end{array}$ & $\begin{array}{l}2,375 \\
(0.81)\end{array}$ & $\begin{array}{l}-141 \\
(-0.87)\end{array}$ & $\begin{array}{l}-113 \\
(-0.57)\end{array}$ & $\begin{array}{c}-167 \\
(-1.79)\end{array}$ & $\begin{array}{l}-209 \\
(-1.29)\end{array}$ & & & & $\begin{array}{c}-21 \\
(-0.44)\end{array}$ & $\begin{array}{l}-995 \\
(-2.21)\end{array}$ & $\begin{array}{c}990 \\
(2.73)\end{array}$ & 2.27 & 0.97 \\
\hline III & -331 & $\begin{array}{l}3,414 \\
(2.52)\end{array}$ & & & & & & & & & & & & $\begin{array}{r}96 \\
(0.72)\end{array}$ & $\begin{array}{r}-8 \\
(0.17)\end{array}$ & $\begin{array}{c}9 \\
(0.31)\end{array}$ & $\begin{array}{c}-38 \\
(-0.48)\end{array}$ & $\begin{array}{c}43 \\
(0.35)\end{array}$ & $\begin{array}{l}330 \\
(0.68)\end{array}$ & 0.91 & 0.86 \\
\hline rV & -63 & $\begin{array}{c}271 \\
(0.008)\end{array}$ & & & & $\begin{array}{l}6,995 \\
(2.02)\end{array}$ & & & & & & & & $\begin{array}{r}28 \\
(0.59)\end{array}$ & $\begin{array}{c}-2 \\
(-0.04)\end{array}$ & $\begin{array}{c}-1 \\
(-0.03)\end{array}$ & $\begin{array}{c}-19 \\
(-0.26)\end{array}$ & $\begin{array}{c}-78 \\
(-0.18)\end{array}$ & $\begin{array}{l}790 \\
(1.57)\end{array}$ & 1.26 & 0.88 \\
\hline$v$ & -453 & & $\begin{array}{l}6.775 \\
(3.01)\end{array}$ & & & & & & & & & & & $\begin{array}{r}12 \\
(0.24)\end{array}$ & $\begin{array}{c}-79 \\
(-1.34)\end{array}$ & $\begin{array}{c}62 \\
(2.21)\end{array}$ & $\begin{array}{l}-24 \\
(-0.32)\end{array}$ & $\begin{array}{c}97 \\
(0.83)\end{array}$ & $\begin{array}{l}291 \\
(0.66)\end{array}$ & 1.18 & 0,88 \\
\hline $\mathrm{vr}$ & -176 & & $\begin{array}{l}1,575 \\
(0.38)\end{array}$ & & & & $\begin{array}{l}5,982 \\
(1.51)\end{array}$ & & & & & & & $\begin{array}{r}17 \\
(0.35)\end{array}$ & $\begin{array}{c}-67 \\
(-1.15)\end{array}$ & $\begin{array}{c}60 \\
(2.22)\end{array}$ & $\begin{array}{c}-22 \\
(-0.31)\end{array}$ & $\begin{array}{l}-583 \\
(-1.25)\end{array}$ & $\begin{array}{l}762 \\
(1.44)\end{array}$ & 1.25 & 0,84 \\
\hline VII & -442 & & & $\begin{array}{l}9,251 \\
(4.92)\end{array}$ & & & & & & & & & & $\begin{array}{r}86 \\
(2.96)\end{array}$ & $\begin{array}{r}26 \\
(0.89)\end{array}$ & $\begin{array}{l}-80 \\
(-5.33)\end{array}$ & $\begin{array}{c}-37 \\
(-0.64)\end{array}$ & $\begin{array}{c}83 \\
(0.92)\end{array}$ & $\begin{array}{l}-186 \\
(-0.54)\end{array}$ & 1.36 & 0.92 \\
\hline vin & -101 & & & $\begin{array}{l}2,761 \\
(1.00)\end{array}$ & & & & $\begin{array}{l}7,982 \\
(2.88)\end{array}$ & & & & & & $\begin{array}{r}90 \\
(3.75)\end{array}$ & $\begin{array}{r}30 \\
(1.20)\end{array}$ & $\begin{array}{l}-80 \\
(-6.15)\end{array}$ & $\begin{array}{c}-29 \\
(-0.59)\end{array}$ & $\begin{array}{l}-797 \\
(-2.54)\end{array}$ & $\begin{array}{c}384 \\
(1.09)\end{array}$ & 1.60 & 0.94 \\
\hline IX & -480 & & & & $\begin{array}{l}9,430 \\
(4.18)\end{array}$ & & & & & & & & & $\begin{array}{r}49 \\
(1.58)\end{array}$ & $\begin{array}{c}84 \\
(2.71)\end{array}$ & $\begin{array}{c}33 \\
(1.32)\end{array}$ & $\begin{array}{l}-100 \\
(-1.40)\end{array}$ & $\begin{array}{c}-49 \\
(-0.44)\end{array}$ & $\begin{array}{c}14 \\
(.003)\end{array}$ & 1.22 & 0.89 \\
\hline $\mathrm{x}$ & -185 & & & & $\begin{array}{l}4,275 \\
(1.60)\end{array}$ & & & & $\begin{array}{l}7,970 \\
(2.76)\end{array}$ & & & & & $\begin{array}{r}48 \\
(1.77)\end{array}$ & $\begin{array}{c}71 \\
(2.63)\end{array}$ & $\begin{array}{l}-46 \\
(-2.09)\end{array}$ & $\begin{array}{l}-50 \\
(-0.78)\end{array}$ & $\begin{array}{l}-885 \\
(-2.79)\end{array}$ & $\begin{array}{c}311 \\
(0.86)\end{array}$ & 1.67 & 0.92 \\
\hline
\end{tabular}

The t-values for the $P_{m}$ co-efficients in Period II where model variants include an interaction term are: II $P_{m t}(2.373), P_{m t-1}(2.663), P_{m t-2(0.442)}, P_{m t-3}(1.720) ;$ IV $P_{m t}(3.325)$; VI $P_{m t-1}(3.40)$, VIII $P_{m t-2}(6.368)$; $X \cdot P_{\text {mt-3 }}(5.558)$. 
none of the milk price or interaction term parameter estimates is significant in model variant II. This is due to a high standard error of the parameter estimates arising out of a high degree of multicollinearity and the. low number of degrees of freedom. The milk price parameter estimates are reduced substantially in model variant II whereas the parameter estimates for the interaction terms are high. The parameter estimates of $\mathrm{P}_{\mathrm{mt}}$ and $\mathbf{P}_{\mathrm{mt}-1}$ are significant for Period II.

Model variants III, V, VII and IX give parameter estimates of the milk price variables which are all larger than in model $I$ and all of which are significant at the 5 per cent level. The parameter estimate of the explicit milk price variable is reduced and is insignificant with the introduction of an interaction term in models IV, VI, VIII and X. The parameter estimate of the interaction term is largest and significant at the 5 per cent level in the case of $\mathrm{P}_{\mathrm{mt}-2}$ and $\mathrm{P}_{\mathrm{mt}-3}$, while the parameter estimates of the milk price variables are significant in all cases in Period II.

The parameter estimates of the livestock price variables have all got the expected sign in model variants I and II and are significant at the 5 per cent level in three out of eight cases. Although the low level of significance of many of the principal component parameter estimates in model variants III to $\mathrm{X}$ might suggest a multicollinearity problem, this was not in fact the case. Klein's (1962) test suggests that the degrees of collinearity existing was not harmful. The Gini co-efficient has the expected sign in all but one equation, but is only significant in model variant II. The dummy variable for the Calved Heifer Grant Scheme has a negative co-efficient but is insignificant in all cases.

This latter result combined with that of Killen (1978), where the Calved Heifer Grant Scheme was found to contribute significantly to the size of the breeding herd, suggests that the scheme affected primarily the non-dairy herd.

Thus, in general, the response to changes in the milk price variables was greater while under the EEC influence than prior to this period. This is possibly due to the high expectation created by the EEC price levels, the greater certainty in milk returns and the ease of investment finance. Despite the fact that beef prices also increased substantially in the post-EEC period the fluctuations in beef prices continued, making investment in dairying a more attractive prospect from both the farmers' and the banks' point of view. The expectations of the farmers were confirmed by the new enthusiasm of the banks to lend and thus the high responsiveness in milk supply resulted.

The elasticity of milk supply with respect to the milk/input price ratio was largest for $\mathrm{P}_{\mathrm{mt}-2}$ at 1.4 in model variant I (Table 2). The price elasticity of milk supply over four years was 3.6. The price elasticities for Period I are 
Table 2: Price elasticities* of creamery milk supply

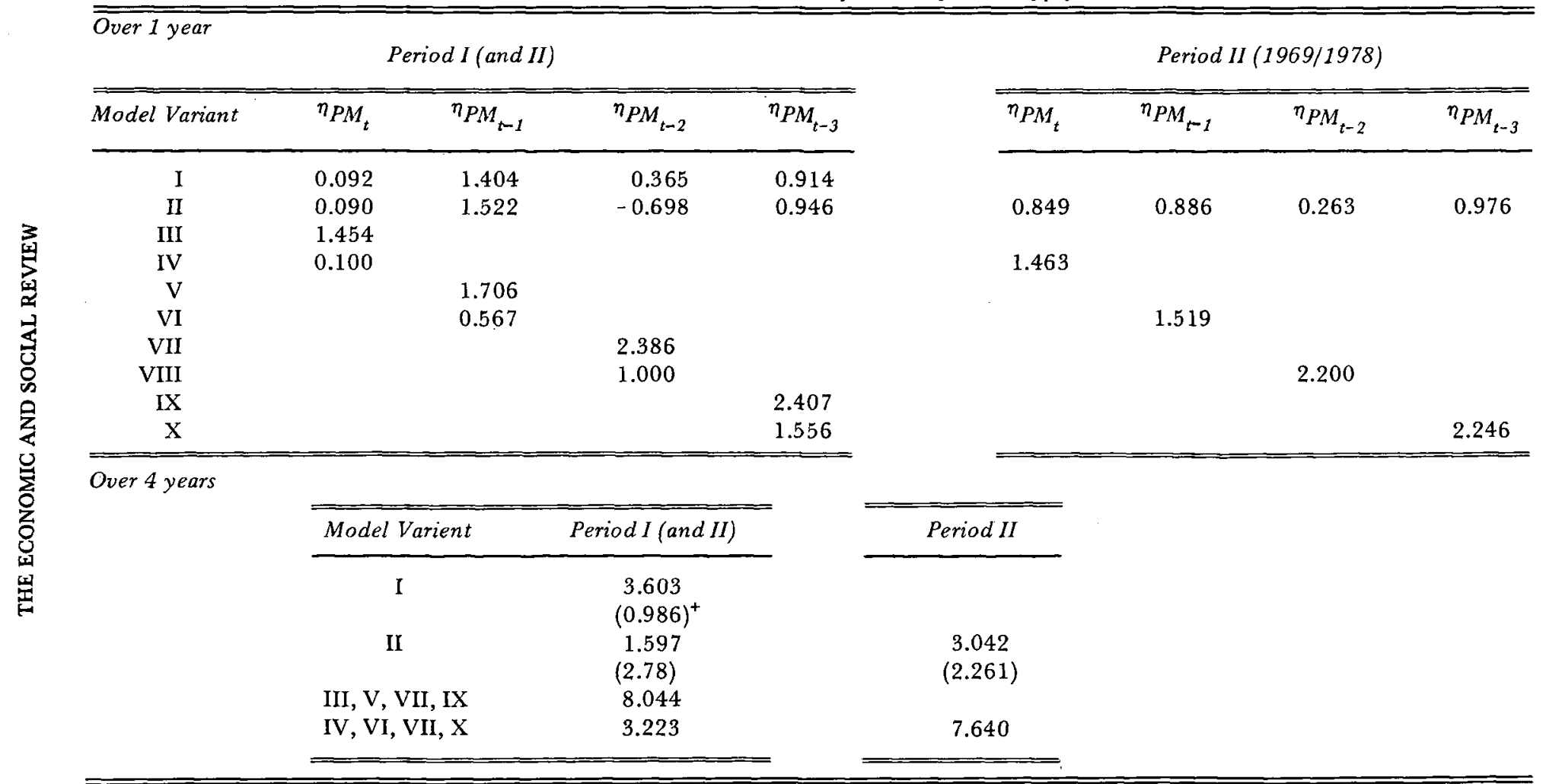

*Elasticities are calculated at the mean values.

+Standard error of elasticity (since the standard errors of the long run elasticities of variants III to X involve standard errors of coefficients in different equations, which renders them $\stackrel{\infty}{\varrho}$ difficult to interpret, they have been omitted). 
much reduced in model variant II while the elasticities in Period II are similar to those found in model variant I. The price elasticities for the milk/ input price ratio in model variants III, V, VII and IX are much increased over those in model variant $I$ with the highest elasticity for $P_{m t-3}$ at 2.4. The price elasticity over 4 years is 8 .

The pattern of results found in moving from variants III, V, VII and IX to variants IV, VI, VIII and X is similar to that found in moving from variant I to variant II. The elasticities for Period II are similar to those found where there was no period differentiation, whereas those for Period I are much reduced. This supports the results of variant II.

Thus one can conclude that the elasticity of creamery milk supply over four years with respect to the milk/input price ratio was between 3.6 and 8 , considering the complete study period. However, on period differentiation the four year price elasticity of milk supply was between 1.6 and 3.2 over Period I and between 3 and 7.6 in Period II.

The milk/input price ratio did rise at a faster rate in the second period than in the first period, being 2.6 per cent per annum in Period I and 3.8 per cent per annum in Period II. Perhaps the faster rise in the price ratio also gave rise to greater optimism and expectations.

However, the price variable did have positive and negative fluctuations over the whole study period which leads to some confidence in predicting response if the price ratio was to decline.

\section{SUMMARY AND CONCLUSIONS}

This article was addressed to estimating the responsiveness of creamery milk supply in Ireland to changes in the ratio of milk price to agricultural input price. A basic model was constructed from which the parameters were estimated, tested for significance and used to estimate price elasticities. The basic model was first adjusted by introducing interaction terms to test for significance of response between Period I and Period II. Problems of multicollinearity and too many variables did not allow the response differences to show up significantly. The step by step isolation of the individual price effects showed that the milk supply responds significantly to each milk price variable with the highest response coming 2 to 3 years after a price change. The introduction of interaction terms into these adjusted models show up significant differences between responses to milk price change in Period I and Period II. The elasticities derived from these results indicate that producers were about twice as responsive to milk price changes in Period II than in Period I.

The implications of milk price for the future changes in milk supply depends on the extent to which producers continue to respond as they did 
over the 1969-78 period or whether they revert to a pre-1969 level of responsiveness. It might reasonably be expected that as the rate of price increase declines over the longer term, producers' responsiveness will return to that of pre-1969 period. Even so the level of responsiveness would still be quite high.

These results have thus important policy implications. On the one hand, they indicate the rate at which Irish producers will contribute to an existing EEC milk surplus in response to continuing increases in the milk/input price ratio. On the other hand, it indicates the potential decline in the Irish milk processing industry if the milk/input price ratio were to drop.

\section{REFERENCES}

BUTTIMER, D.J., 1972. "Supply Response in the Irish Dairy and Beef Herds, 1953-1970: An Economic Exercise", Irish Journal of Agricultural Economics and Rural Sociology, Volume 4, No. 1 .

HALVORSON, H.W., 1958. "Response of Milk Production to Price", Journal of Farm Economics, Volume 40, December.

KEANE, M., 1976. "Projections of Change in Creamery Supplier Structure”, Irish Journal of Agricultural Economics and Rural Sociology, Volume 6, No. 2.

KILLEN, L.M., 1976. "Cattle Production: past trends and short term outlook", Irish Journal of Agricultural Economics and Rural Sociology, Volume 6, No. 2.

KLEIN, L.R., 1962. Introduction to Econometrics, London: Prentice-Hall International. O'CONNOR, R., 1972. "Projections of Irish Cattle and Milk Output under E.E.C. conditions", The Economic and Social Review, Volume 3, No. 3.

O'NEILL, F.K., and P. HERLIHY, 1977. "Future Milk Supplies: Forecasts and Alternatives". Conference: Dairying Now and in the Future - Volume and Seasonal Patterns. Dublin: An Foras Talúntais, ERWRC, November.

PRATO, A.A., 1973. "Milk Demand, Supply and Price Relationships, 1950-1968", A merican Joumal of A gricultural Economics, Volume 55, No. 2. 